Clim. Past, 9, 1331-1343, 2013

www.clim-past.net/9/1331/2013/

doi:10.5194/cp-9-1331-2013

(c) Author(s) 2013. CC Attribution 3.0 License.

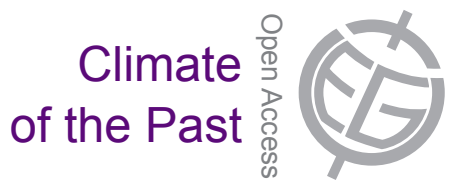

\title{
Documentary-derived chronologies of rainfall variability in Antigua, Lesser Antilles, 1770-1890
}

\author{
A. J. Berland, S. E. Metcalfe, and G. H. Endfield \\ School of Geography, University of Nottingham, University Park, NG7 2RD, UK
}

Correspondence to: A. J. Berland (lgxajb@nottingham.ac.uk)

Received: 26 February 2013 - Published in Clim. Past Discuss.: 25 March 2013

Revised: 26 May 2013 - Accepted: 27 May 2013 - Published: 25 June 2013

\begin{abstract}
This paper presents the first extensive reconstruction of precipitation variability in the Lesser Antilles using historical documentary sources. Over 13250 items of documentation pertaining to Antigua from the period 1769-1890 were consulted, including missionary, plantation and governmental papers as well as contemporary scholarly publications. Based on the predominant meteorological conditions observed throughout the island, each "rain-year" (December-November) was assigned one of five classifications (very wet, wet, "normal", dry and very dry). Local weather references relating to seven plantations in centraleastern Antigua were grouped according to dry (DecemberApril) and wet seasons (May-November), each of which were also categorised in the aforementioned manner. Results comprise individual island-wide and central-eastern Antiguan chronologies of relative precipitation levels, spanning the rain-years $1769-70$ to $1889-90$ and $1769-70$ to 1853-54 respectively. The former is compared with available instrumental data for the years 1870-1890. Significant dry phases are identified in the rain-years 1775-80, 1788-91, 1820-22, 1834-37, 1844-45, 1859-60, 1862-64, 1870-74 and 1881-82, while wet episodes were 1771-74, 1833-34, 1837-38, 1841-44, 1845-46 and 1878-81. Evidence for major wet and dry spells is presented and findings are evaluated within wider historical and palaeoclimatic contexts.
\end{abstract}

\section{Introduction}

The Lesser Antilles, in the Southern Caribbean, are subject to highly variable interannual precipitation and prolonged periods of rainfall abundance or deficiency, which can have profound socio-economic consequences. Widespread drought in 2009-2010 witnessed a $20 \%$ drop in total agricultural production in St. Vincent and the Grenadines, the loss of nearly half the Dominican banana crop and serious water shortages, food price increases and wildfire damage in many islands (Farrell et al., 2010). Furthermore, the Intergovernmental Panel on Climate Change has identified the circum-Caribbean as a region of "increased vulnerability to extreme events" of this nature in the future (Magrin et al., 2007: p. 606).

Investigations of historical climate fluctuations are essential for understanding the mechanisms that modulate the occurrence of extreme events and, thus, forecasting possible changes in their frequencies (Mock, 2007). While many high-resolution reconstructions of pre-instrumental hurricane activity and sea surface temperatures (SSTs) have been undertaken in the Caribbean (e.g. Chenoweth, 2006; Kilbourne et al., 2008), there are few comparable studies of precipitation variations. Research by Chenoweth (2003) and Mendoza et al. (2007) for Jamaica and the Yucatan Peninsula respectively illustrate that historical records represent a valuable source of information about past rainfall variability.

This paper presents the first extensive precipitation reconstruction in the Caribbean. A range of published and unpublished sources pertaining to Antigua are employed to construct sequences of annual and seasonal rainfall variability in the island, spanning 1770-1890 and 1770-1854 respectively. The evidence for major wet and dry spells, interpretation of 
findings and scope for comparison with other palaeoclimate records are discussed.

\section{Study location and climatic setting}

Antigua is situated in the northern Lesser Antilles (Fig. 1). It is a small $\left(\sim 280 \mathrm{~km}^{2}\right)$, predominantly low-lying limestone island (40-120 m a.s.l.) with a mountainous volcanic zone in the southwest (peaks $>300$ ma.s.l.). Average temperatures fluctuate from 25 to $28^{\circ} \mathrm{C}$ throughout the year. Mean annual precipitation is $1184 \mathrm{~mm}, 70-80 \%$ of which typically falls in the wet season between May and November (Antigua and Barbuda Meteorological Service, henceforth ABMS, 2013). An initial precipitation peak is normally experienced in May, a relative minimum in June and a maximum in OctoberNovember (Fig. 2a). Spatial variations in precipitation occur in accordance with the island's topography; from 1992 to 2011, mean annual rainfall at Jolly Hill in the volcanic zone was $1393 \mathrm{~mm}$, while at Coolidge in the north and Renfew Park in the central "lowlands" (Fig. 1) the equivalent figures were 1044 and 1134 respectively (ABMS, 2013).

The annual rainfall regime of the Caribbean is driven by seasonal migrations of the Inter-Tropical Convergence Zone (ITCZ) and North Atlantic High (NAH). During the boreal winter, the former occupies an approximately equatorial position and the latter spreads from the Atlantic Ocean to the North American landmass. This results in strong easterlies and relatively low SSTs in the region, inducing subsidence and dry conditions. Precipitation arises from occasional incursions of mid-high-latitude cold fronts, though these rarely extend further southeast than Puerto Rico (Taylor and Alfaro, 2005). Between late spring and autumn the NAH shifts offshore and poleward, the ITCZ shifts to a latitude of 6$10^{\circ} \mathrm{N}$, SSTs increase and the trade winds converge over the basin, encouraging convective rainfall (Hastenrath, 1976; Gianni et al., 2000). African easterly waves propagate into the Caribbean from June to early November, intermittently developing into tropical cyclones, and contribute significantly to summer precipitation totals (Taylor and Alfaro, 2005).

Antigua experiences considerable interannual precipitation fluctuations (Fig. 2b). At a regional scale, the El NiñoSouthern Oscillation (ENSO) and North Atlantic Oscillation (NAO) are considered important independent drivers of such variability (Gianni et al., 2001a). The former affects early and late stages of the wet season differently. Its warm (cold) phase is associated with drier-than-normal (wetterthan-normal) conditions in the Caribbean from July to October of the year of onset and above (below)-average precipitation around April-June the following year (Ibid.). Caribbean rainfall is negatively correlated with the NAO, its positive phase suppressing precipitation until May-June, after which its effects subside gradually (Gianni et al., 2001b).
Table 1. Details of archival sources consulted and referencing codes used henceforth.

\begin{tabular}{ll}
\hline Archive & $\begin{array}{l}\text { Sources consulted and referencing } \\
\text { codes }\end{array}$ \\
\hline $\begin{array}{l}\text { British Library, } \\
\text { London }\end{array}$ & $\begin{array}{l}\text { Microfilm copies of unpublished pa- } \\
\text { pers relating to the Antiguan estates of } \\
\text { the Codrington Family, 18th-19th cen- } \\
\text { turies. Includes correspondence, ac- } \\
\text { counts and miscellaneous documents } \\
\text { (series COD/C, COD/A and COD/E } \\
\text { respectively). }\end{array}$ \\
\hline $\begin{array}{l}\text { Somerset } \\
\text { Archive and }\end{array}$ & $\begin{array}{l}\text { Unpublished book of letters from } \\
\text { various correspondents in Antigua } \\
\text { to Sir Clement Tudway, 1759-84 } \\
\text { (DD/TD/15/6); type-written transcripts } \\
\text { of letters and monthly journals relating } \\
\text { to the Tudway Family's Antiguan es- } \\
\text { tates, 1768-1858 (T/PH/swd series). }\end{array}$ \\
\hline $\begin{array}{l}\text { Unpublished correspondence sent from } \\
\text { Lational }\end{array}$ & $\begin{array}{l}\text { the governor of Antigua to government } \\
\text { officials in London, 18th-19th cen- } \\
\text { turies (series CO7 and CO152); annual } \\
\text { "Blue Books" of statistics produced by } \\
\text { the colonial administration from 1821 } \\
\text { (series CO10 and CO157). }\end{array}$ \\
\hline $\begin{array}{l}\text { Unpublished letters from Moravian } \\
\text { missionaries in Antigua, 1783-1818 } \\
\text { (OL series); published "Periodical Ac- }\end{array}$ \\
counts" of the Moravians' oversees \\
work, including copies, extracts and \\
syntheses of original letters from 1790 \\
(PA series).
\end{tabular}

\section{Data sources}

This study employs a variety of archival sources held in the United Kingdom, in the form of plantation, missionary and government records (Table 1). These consist primarily of unpublished, precisely dated documents written in Antigua by permanent residents of the island.

Plantation records represent a major part of Antigua's documentary heritage. From the seventeenth through nineteenth centuries, the principal driver of the colonial economy was sugar production, to which most cultivable land was dedicated. This research utilises papers relating to the sugar estates of the Britain-based Codrington and Tudway families. By the mid-1700s, these families respectively owned five and two plantations located in central-eastern Antigua (Fig. 1), which they retained until the early twentieth century. Documentation concerning these properties was compiled by various individuals connected with the sugar industry, chiefly a relatively small number of plantation managers who served for up to $19 \mathrm{yr}$. Being crucial for sugarcane yields, 


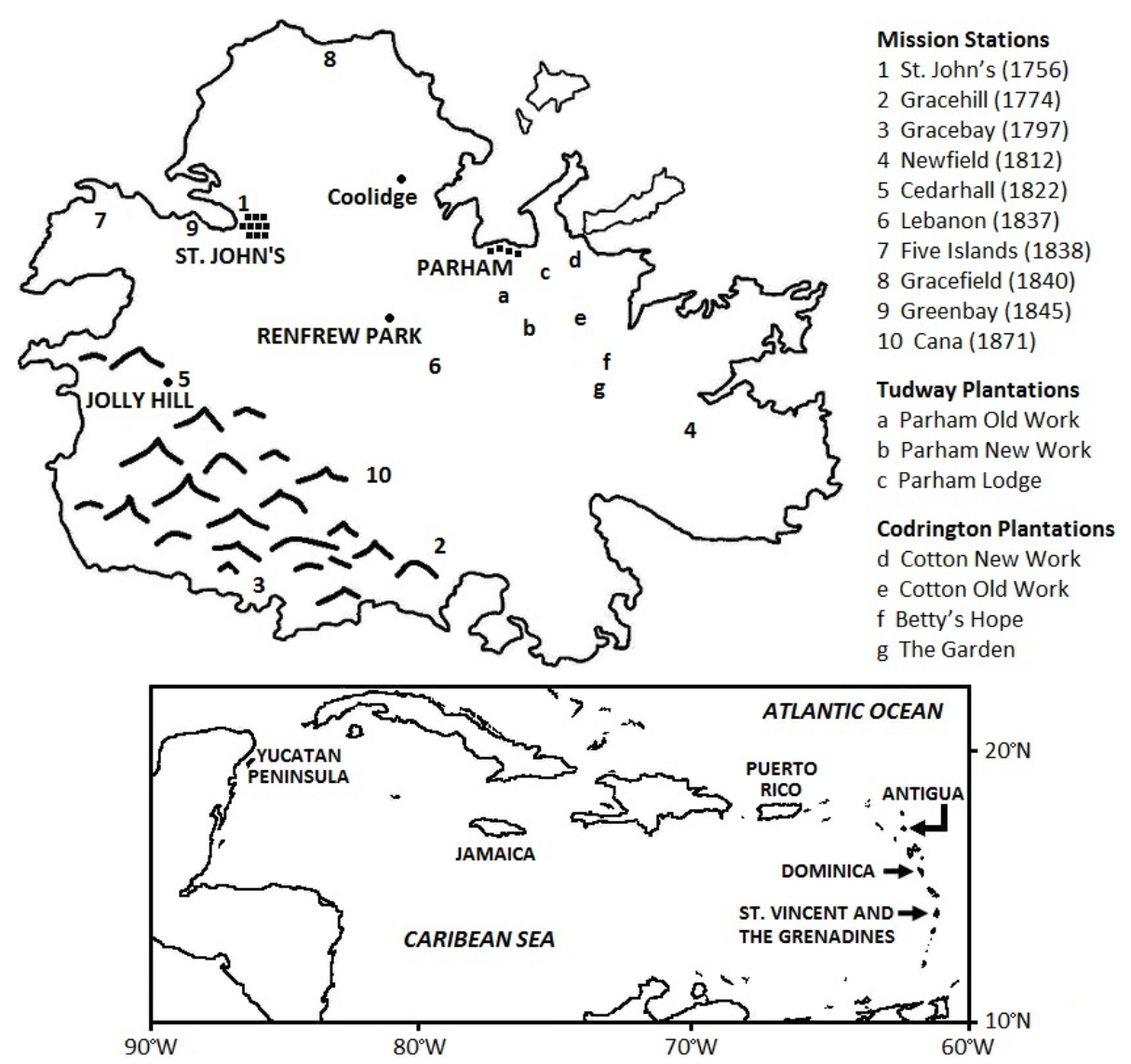

Fig. 1. Map displaying locations mentioned in the text. Dates of mission station establishment shown in brackets.

meteorological conditions received frequent commentary in their correspondence, often enabling the identification of monthly-seasonal variability.

Missionary correspondence pertains to the Society for the Furtherance of the Gospel, known also as the Moravians, whose evangelical work began at their mission station in St. John's in 1756 . Their operations expanded substantially during the subsequent century, with the establishment of another nine stations throughout Antigua (Fig. 1). Letters, mission diaries and miscellaneous reports were sent regularly to Moravian headquarters in Britain and Germany. Such documentation formed the basis of voluminous "Periodical Accounts", which reported on the spiritual and physical welfare of the missionaries and their congregations globally.

Of particular value due to its abundance and temporal continuity was the correspondence of the governors of Antigua, which kept the British Colonial Office abreast of affairs in the island. From 15 to 258 letters and enclosures were sent every year, covering topics ranging from the economy to natural disasters. Enclosures comprised copies of legislative minutes, statistical data and thematic reports prepared by government officials. Complementary to this material were the colony's "Blue Books", which consisted of annual statistical compendia including demographic, economic and, occa- sionally, meteorological data. Overall, both government and missionary records were a rich source of information on meteorological extremes, furnishing detailed accounts of major droughts and periods of excessive rainfall. They also afforded an island-wide perspective, including both general and location-specific reports.

In addition to archival collections, the following contemporary publications were consulted: Collins (1792), Lanaghan (1844), Nicholson (1866), Oliver (1894), SFG (1856), Sturge and Harvey (1838) and Young (1801). These include histories of Antigua and the Moravian missionaries, travel accounts and medical studies.

\section{Methods of analysis}

A method akin to that of Nash and Endfield (2002) was adopted for a semi-quantitative analysis of relative precipitation levels. All material from 1769 to 1891 was read, where possible chronologically, and passages regarding the state of the climate transcribed verbatim, retaining historical spelling conventions. This information consisted of (1) descriptions of extreme weather events and (2) anecdotal observations of short- or long-term variations of weather conditions, such 


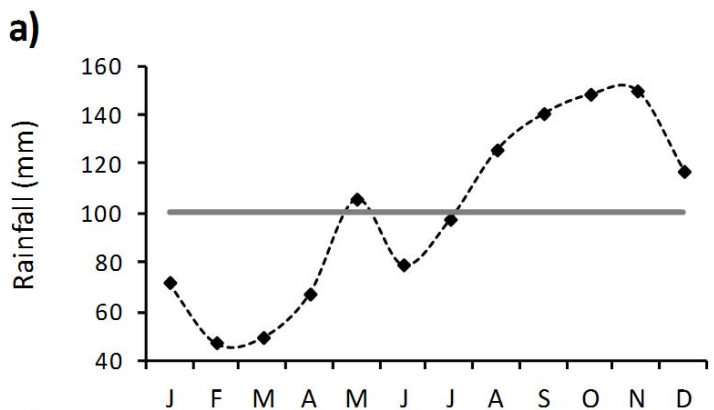

b)

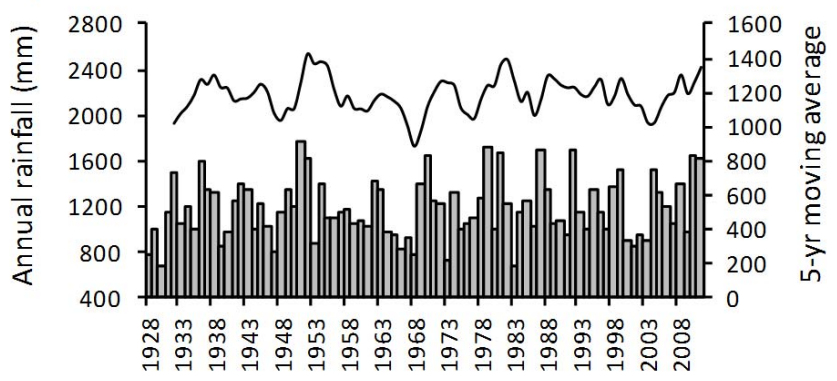

Fig. 2. (a) Mean monthly rainfall derived from national data, 19282011. Solid grey line represents average of monthly mean values. (b) National annual rainfall totals, 1929-2011 (grey bars) and $5 \mathrm{yr}$ moving average (black line). Data courtesy of ABMS.

as remarks about the timing of rainy season onset or prolonged wetter or drier periods. Information of potential value for contextualising such findings was also recorded. This included indirect evidence of meteorological conditions (e.g. references to crop yields or water availability), details of non-meteorological factors implicated in harvest failures or food shortages and comments about the environment unrelated to climate. Most accounts specified the dates of the phenomena to which they referred. Where dates were unspecific or omitted, comparison with other sources often enabled their timing to be constrained. Records for which it remained impossible to assign even approximate dates were excluded from the reconstruction. Particular care was taken when interpreting published sources, as it was occasionally unclear whether these were based on direct observations. Such accounts were treated as auxiliary to firsthand reports. Transcripts of the Tudway letters and relevant entries in the Moravians' Periodical Accounts were compared with over 100 original documents used to compile those records. This revealed no significant discrepancies between sources.

The data collected was used to produce an island-wide and a central-eastern Antiguan precipitation record, which are discussed in the following sections.

\subsection{Island-wide precipitation reconstruction}

All direct references to meteorological phenomena (i.e. categories 1 and 2 above) throughout Antigua were compiled chronologically. These consisted of passages discussing weather patterns or events experienced generally in the island or at multiple disparate locations in a given period. Isolated references to conditions at a single location were excluded. The selected extracts were analysed in accordance with the Antiguan rain-year (December-November). Based on the predominant balance of climatic conditions reported, each rain-year from 1769-70 to 1889-90 was categorised as one of the following: very wet, wet, "normal" (i.e. seasonable rains), dry or very dry. Such classifications have been used widely to reconstruct precipitation variability in southern Africa (e.g. Nash and Endfield, 2002; Kelso and Vogel, 2007; Nash and Grab, 2010). Examples of extracts typifying each category are shown in Table 2 . To gauge the confidence of classification assignations, the results of this process were compared with the total number of sources and data points (i.e. references to rainfall or a lack thereof at a given time) available for each rain-year.

Thirty-four rain-years were not categorised because of a lack of conclusive weather references. For all of these but one, between 40 and 187 documents written by a variety of observers were consulted. Given the temporal regularity and abundance of this documentation, it is reasonable to conjecture that if major deviations from "normal" conditions had been experienced they would have been reported. These rainyears have thus been tentatively labelled as "assumed normal" to indicate that this classification lacks explicit confirmation. Only five documents were available for $1786-87$, so this rain-year is unclassified.

The potential for calibrating results is limited by the absence of standardised instrumental data prior to 1928 . Nonetheless, a continuous series of monthly rainfall figures recorded at St. John's public library is provided by Oliver (1894) for 1870 to 1887 and the Blue Books for 1887 to 1889. Equivalent figures are included in the 1890 Blue Book for a "government laboratory" in St. John's. Auchinleck (1956) presents another series, consisting of annual rainfall totals for the period of 1874-1949 averaged from measurements taken throughout Antigua. The documentaryderived chronology was compared with annual totals for each rain-year calculated from the St. John's series and figures for corresponding calendar years provided by Auchinleck. This revealed broad agreement between data sets. Certain caveats should, however, be acknowledged. Despite thorough examination of documentary sources, very little information was encountered about the instruments and procedures used to obtain the rainfall series in question. Of the measurements taken at the St. John's library, all that is known is that a rain gauge of unspecified design was suspended at a height of 12 feet $(\sim 3.66 \mathrm{~m})$ above ground-level. Meanwhile, Auchinleck (1956) notes only that his yearly rainfall totals were obtained by calculating the mean of the annual rainfall measured at 40 to 70 "stations" throughout Antigua. The number of station records available for each year is not specified, making Auchinleck's annual totals not strictly comparable. Such uncertainties over precision and homogeneity are often 


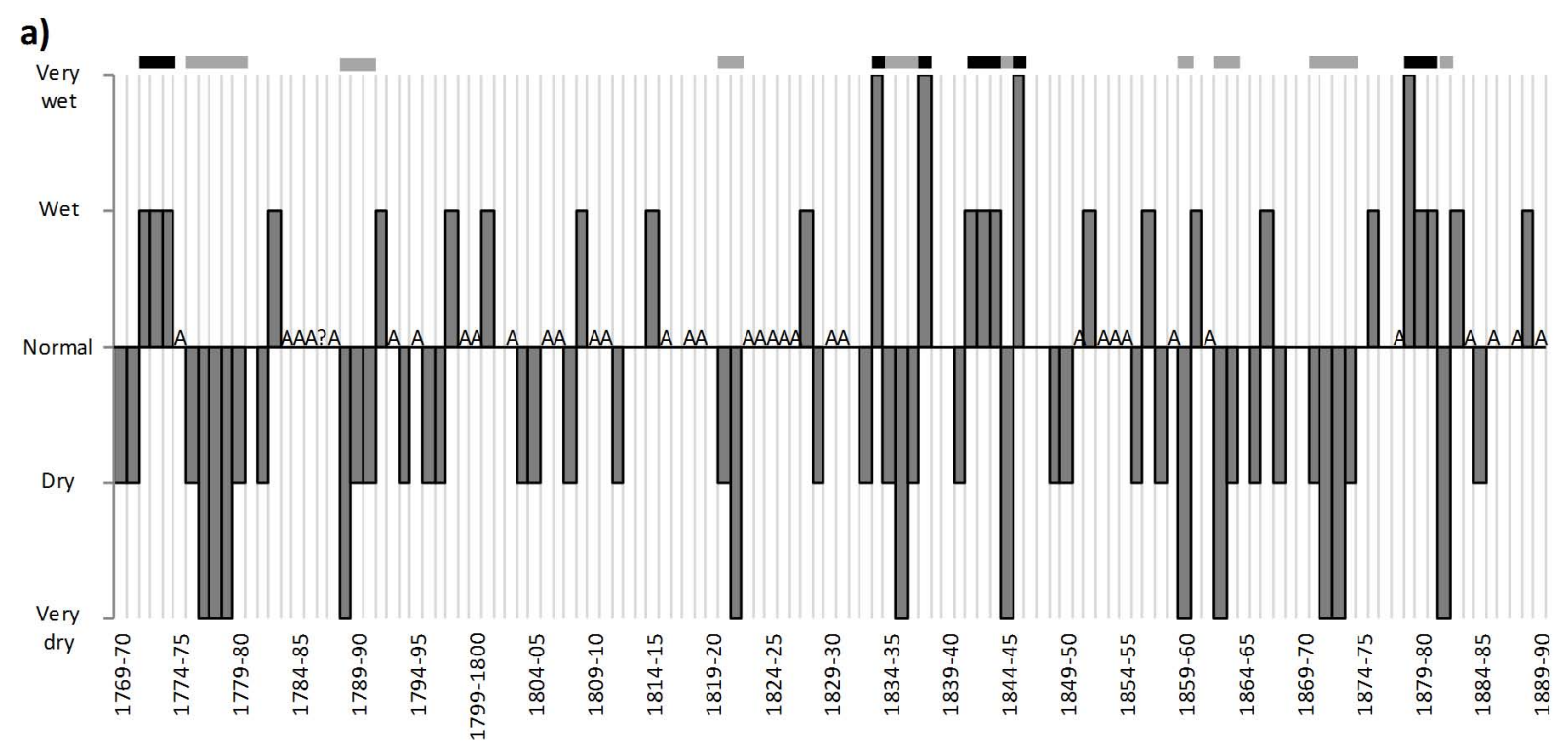

b)
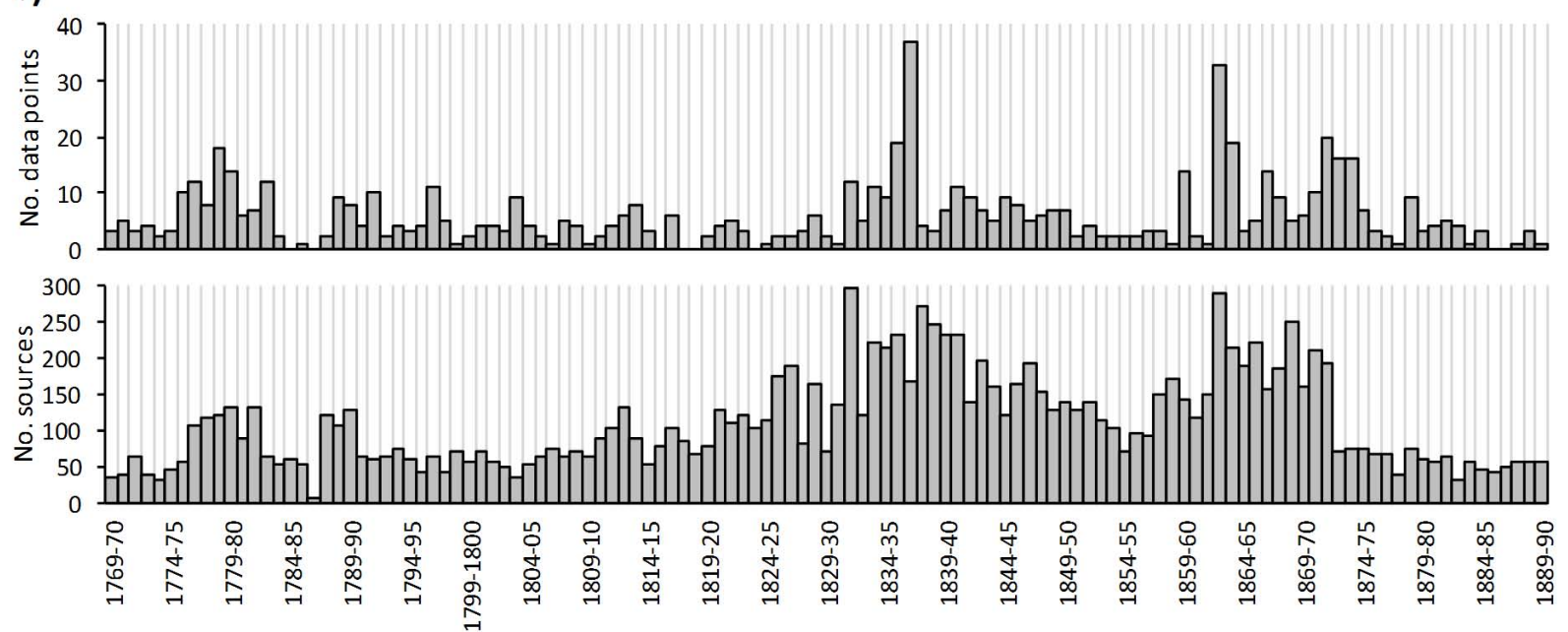

Fig. 3. (a) Document-derived chronology of predominant rainfall conditions throughout Antigua, 1769-70 to 1889-90. A and ? denote assumed "normal" and unclassified rain-years respectively. Major dry (wet) phases highlighted in grey (black) at top of chart. (b) Number of data points and documents available for each rain-year.

inevitable in unstandardised instrumental data (Chenoweth, 2003). It is, however, noteworthy that the annual precipitation cycle exhibited by the monthly means of the St. John's data (not shown) largely matches that derived from modern data (Fig. 2a).

\subsection{Central-eastern Antiguan precipitation reconstruction}

Plantation papers related chiefly to estates situated within a relatively small area in central-eastern Antigua (Fig. 1). These sources reported regularly on meteorological conditions, often enabling local inter-seasonal variability to be identified. To this end, all direct references to weather phenomena were collated and analysed according to the dry sea- son (December-April) and wet season (May-November) of each rain-year. The fivefold classification system described previously was applied to reflect the predominant conditions reported in each season, with careful consideration of the "normal" weather patterns expected at different times of year. Due to the paucity of relevant records after the mid-1850s, the resulting chronology covers 1769-70 to 1853-54. Within this period, a shortage of data points made it impossible to classify 39 individual seasons. Numbers of documents and data points for each rain-year were, as before, used as an approximate measure of classification confidence. 
Table 2. Examples of statements characteristic of the five classifications assigned to each rain-year.

\begin{tabular}{|c|c|}
\hline Category & Illustrative quote \\
\hline Very wet & $\begin{array}{l}\text { "The quantity of rain which fell during } \\
\text { the year was very remarkable, being much } \\
\text { greater than anyone could remember in for- } \\
\text { mer years... The attendance at church and } \\
\text { school was often thinned by the floods which } \\
\text { poured down in such abundance" (PA Vol. } 15 \\
\text { p. } 79 \text {, Gracehill station diary 1838). }\end{array}$ \\
\hline Wet & $\begin{array}{l}\text { "We have had much rain during the last five } \\
\text { months in Antigua, which has been a great } \\
\text { blessing to the island. There is at present the } \\
\text { prospect of a very large crop." (PA Vol. } 20 \\
\text { p. } 422 \text {, letter from G. Westerby, } 29 \\
\text { December 1852) }\end{array}$ \\
\hline Normal & $\begin{array}{l}\text { "This Island remains perfectly healthy, the } \\
\text { weather seasonable and the Crop in the best } \\
\text { possible State." (CO7/7, Gov. D'Urban to } \\
\text { Earl Bathurst, } 15 \text { January 1821). }\end{array}$ \\
\hline Dry & $\begin{array}{l}\text { "The island throughout its extent requires } \\
\text { abundant and heavy rains. Fortunately show- } \\
\text { ers have been frequent, and have pre- } \\
\text { vented the plants from becoming absolutely } \\
\text { parched, but as yet the crop is by no means } \\
\text { safe. The weather has been for many months } \\
\text { hot and dry..." (CO7/68, W. Walker to Gov. } \\
\text { Macphail, } 24 \text { July 1841). }\end{array}$ \\
\hline Very dry & $\begin{array}{l}\text { "This year's crop has been nearly destroyed } \\
\text { from the severest Drought that was ever } \\
\text { known in this Island, \& ye want of water } \\
\text { is now so very great in many places... yt } \\
\text { if we are soon relieved by plentiful show- } \\
\text { ers, the consequences must be very shock- } \\
\text { ing." (DD/TD/15/6, S. Elliot to C. Tudway, } \\
29 \text { April } 1779 \text { ) }\end{array}$ \\
\hline
\end{tabular}

\subsection{Methodological limitations}

Limitations to the use of historical archives for climate reconstruction and the aforementioned fivefold classification system have been discussed extensively elsewhere (e.g. Pfister et al., 1999; Brazdil et al., 2005; Endfield, 2007; Nash and Grab, 2010) and will receive only brief mention here. First there is the matter of data reliability. All documentary sources have been produced by individuals with unique positionalities influencing their attitudes, biases and environmental awareness. Information is included or excluded from documents reflecting such factors - which determine perceptions of "normal" climatic conditions and the scale of specific events - as well as the intended readership. Secondly, categorisation of rain-years and seasons into discrete classes is inevitably a subjective and generalised representation of climate variability. Often, classifications had to be assigned to reflect drier conditions in certain months counterbalancing wet weather in others (see Sects. 5.1 and 5.2 for examples). When determining yearly classifications, greater weighting was attached to conditions in the wet season, which typically accounts for over $70 \%$ of rainfall. Only rain-years/seasons in which meteorological extremes were reported by multiple observers were classed "very wet" or "very dry". Finally, certain spatial limitations should be considered. Most observers resided either in St. John's or at a limited number of plantations and mission stations. Even with missionaries writing from nine locations across the island by the mid-1800s, news of weather conditions in isolated or sparsely populated areas was chiefly spread by word of mouth. A degree of inaccuracy may be expected in such instances. With respect to the central-eastern Antiguan chronology, small-scale variations in rainfall distribution may introduce some error. On 23 November 1836, Thomas Foote, manager of the Tudways' Old Work estate, wrote the following:

Within the last ten days some heavy rains have fallen to the West and South of us but so partial that the South side of the New Work had more than any other part of it, and not one drop on this [estate] or the Lodge... (T/PH/swd/2, T. Foote to R. Tudway, 23 November 1836)

While this passage identifies local differences in rainfall, others reporting conditions at a particular plantation may not.

\section{Results}

In total, 13258 items of documentation were analysed, producing an almost continuous record of climate data for Antigua spanning 1770-1890. Chronologies of average rainfall conditions throughout the island and at the Tudways' and Codringtons' estates in central-eastern Antigua are shown in Figs. 3a and 5a respectively. The trends displayed should be interpreted with consideration of the availability of documentation and weather references (Figs. $3 \mathrm{~b}$ and 5b). ${ }^{1}$ Table 3 displays classification frequencies for both

\footnotetext{
${ }^{1}$ Kelso and Vogel (2007) propose an alternative manner of conveying the confidence of relative annual precipitation classifications, assigning each a "confidence rating" (CR) of 1, 2 or 3 (1 representing the lowest and 3 representing the highest level of confidence). In the island-wide Antiguan chronology, 73 of the 85 rainyears assigned definitive classifications (i.e. very wet, wet, normal, dry or very dry) would receive a CR of 3 under the system of Kelso and Vogel. The twelve rain-years 1771-72, 1773-74, 1780-81, 1804-05, 1808-09, 1814-15, 1819-20, 1827-28, 183839, 1855-56, 1860-61 and 1876-77 would be awarded CRs of 2. Categorisation of rain-years as "assumed normal" or "unclassified" where evidence was inconclusive eliminates the need for any CRs of 1. With respect to the central-eastern Antiguan reconstruction, Kelso and Vogel's CR system is not strictly applicable, as most
} 
Table 3. Classification frequencies for island-wide and centraleastern chronologies.

\begin{tabular}{|c|c|c|c|}
\hline \multirow[b]{2}{*}{ Category } & \multirow{2}{*}{$\begin{array}{r}\text { Island-wide } \\
\text { data }\end{array}$} & \multicolumn{2}{|c|}{ Central-eastern data } \\
\hline & & $\begin{array}{r}\text { Dry } \\
\text { season }\end{array}$ & $\begin{array}{r}\text { Wet } \\
\text { season }\end{array}$ \\
\hline Very wet & 4 & 2 & 4 \\
\hline Wet & 22 & 4 & 17 \\
\hline Normal & $52 *$ & 18 & 23 \\
\hline Dry & 30 & 27 & 17 \\
\hline Very dry & 12 & 12 & 17 \\
\hline Unclassified & 1 & 22 & \\
\hline Assumed normal & 35 & & \\
\hline
\end{tabular}

* Includes both documented and assumed classifications.

chronologies. Comparison of classifications with available rainfall measurements reveals fair correspondence between documentary-derived and instrumental data sets (Fig. 4).

Results indicate that nine episodes of major drought and six of consistently and/or particularly high rainfall levels were experienced throughout Antigua between 1769-70 and 1889-90 (Fig. 3a). Examples of evidence for the duration, severity and spatial variability of the most significant dry and wet phases will now be presented.

\subsection{Major dry periods}

Evidence suggests that the late 1770 s witnessed the most protracted episode of drought in the study period. After a wet spell in the early-mid-1770s, plantation correspondence records severe precipitation scarcity throughout Antigua from October 1775 until May 1776, followed by seasonable weather in late summer. Widespread drought was then recurrent from October 1776 to October 1780, during which accounts of extreme rainfall deficiency, harvest failure and subsistence crisis were abundant. For example, referring to the Antiguan populace, the governor of the colony wrote the following in May 1779:

Their present Crops are Distroyed [sic] by a long, very long severe Drought; nor have they now any prospect of a succeeding Crop: they have not had a thorough Season of Rain since October was a Twelve Month... Heavan [sic] has denied them not only Seasons but even refreshing Showers from whence they might raise Pulse and Vegetables... (CO152/59, Gov Burt to Lord Germain, 3 May 1779).

Rains in October 1777 were seemingly the only major break in the dry phase. However, several short-lived showery

classifications here were assigned on the basis of descriptions of the progression weather conditions or climate events over intervals of weeks to months, rather than annual/seasonal summaries. spells were documented in the neighbourhood of the Tudway estates the following two years. Precipitation in early-mid1780 was observed to have been limited to other areas. For instance, Mainswete Walrond, manager of the Tudway properties, noted that, while southwest Antigua had experienced "good weather", the rains were "by no means general, $\&$ all the rest of the island... never made so bad a crop" (DD/TD/15/6, M. Walrond to C. Tudway, 29 July 1780). After reportedly mixed conditions in the rain-year 1780-81, precipitation scarcity returned from early 1782 to mid-1783, leading government officials to complain: "for more than seven years... has this unhappy Colony been visited with a Drought" (CO152/63, Legislative petition, 28 May 1783).

Contemporary observations of climatic conditions are relatively sparse in the late 1780s and early 1790s. Nonetheless, retrospective accounts record major precipitation scarcity from 1788 to 1791. An overview of past droughts appearing in an 1830s Moravian mission diary recollected that "in 1789 there was no rain for seven months" (PA, Vol. 14, p. 444, St. John's diary, 21 January 1837), while a government report on the same topic dated 1877 stated that "prolonged drought... almost entirely destroyed the growing crop" in 1789 and 1790 (CO152/129, report of E. Baynes, 14 May 1877). Conditions in 1791 are documented chiefly in travel writings. For instance, the diary of visiting physician William Young notes that despite the occurrence of "partial rains" that year, the rainy season had "again failed" (Young, 1801: 282). Central-eastern Antiguan weather references are more abundant for 1790 and 1791, documenting intermittent wet spells from winter to early summer and deficient precipitation during the rest of the wet season in both years.

The next major island-wide drought for which there is substantive evidence occurred in the early 1820s. This may reflect the relative shortage of climate references in the first three decades of the 1800s (Fig. 3b). Indeed, even the severe dry spell of 1820-22 is documented only in administrative correspondence. A governor's despatch dated 3 October 1822, containing five enclosures on the matter, conveyed news of "a most severe drought during the last and the present year, such as has not been known for more than thirty years" (CO7/7, Gov. D'Urban to Earl Bathurst, 3 October 1822, Enclosure 4). One report prepared by the legislature a month earlier noted the following:

From the scourge of excessive drought... our Public reservoirs and receptacles for wholesome Water, are in most instances empty, and in all much exhausted, our Sugar Crop is reduced to one fourth of its averaged amount, and our ground Provisions and other internal means of subsistence almost totally annihilated. (Ibid., Enclosure 3)

A major drought episode in 1834-37 is the best documented in this study, with 111 references to climatic conditions available for those rain-years. Precipitation scarcity is 
a)

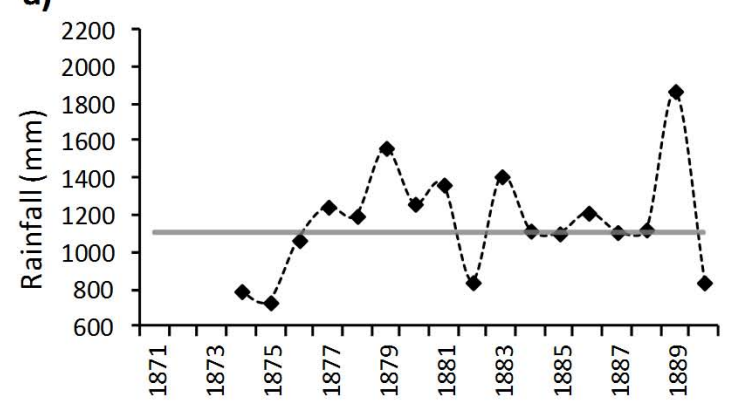

b)

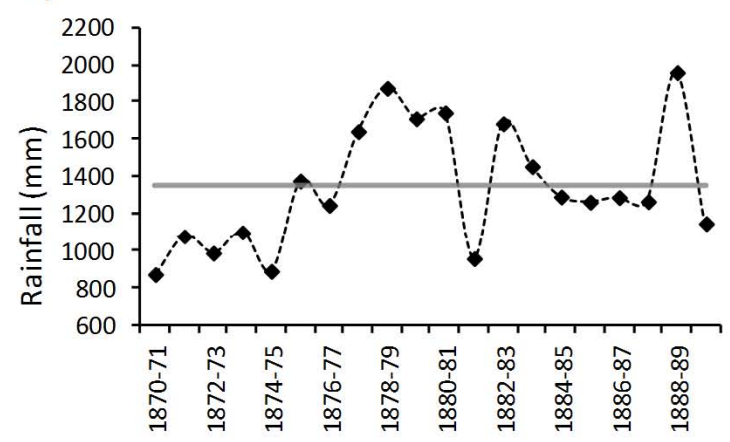

c)

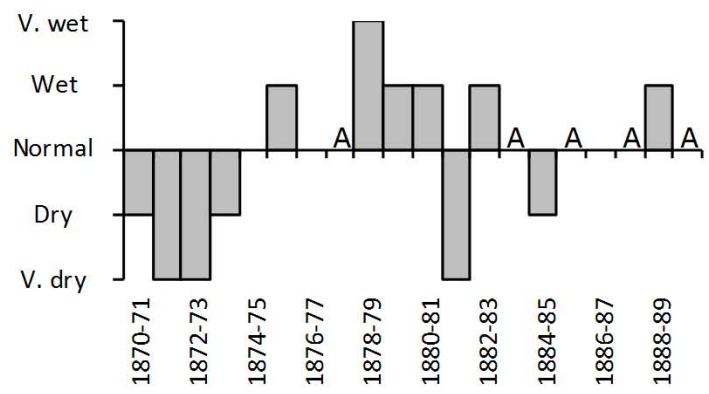

Fig. 4. (a) Instrumental rainfall data for Antigua, 1874 to 1890, averaged from multiple measurements by Auchinleck (1956). Black diamonds display annual totals for calendar years; grey line displays annual mean for calendar years 1874-1949. (b) Instrumnetal rainfall data for St. John's, 1870-71 to 1889-90, from Oliver (1894), CO157/2, CO157/3 and CO157/4. Black diamonds indicate totals for each rain-year; grey line represents annual mean. (c) Documentary-derived chronology of average rainfall conditions throughout Antigua, rain-years 1870-71 to 1889-90. A denotes assumed "normal" classification.

recorded across Antigua during much of 1834-35, save August, which saw moderate rains. There is then evidence of extremely dry conditions from late 1835 through early summer 1837 , including multiple reports of up to " 13 months without any rain" (PA, Vol. 14, p. 444, St. John's diary, 21 January 1837). By spring 1837, government correspondence had become dominated by discussion of this "most severe, protracted and unprecedented drought" and its socioeconomic implications (CO7/47, Gov. Colebrooke to Lord
Glenelg, 19 May 1837). Dry conditions appear, however, to have been alleviated in the south-western "highlands" by occasional precipitation in mid- and late 1836. Central-eastern Antigua also experienced major drought in 1836 and 1837, but favourable weather in August-December 1835.

Successive rain-years of severe drought are next documented in the period of 1862-64. After abundant precipitation towards the end of 1862, the first weather observation in 1863, dated 12 June, noted that soils in the outskirts of St. John's had been "baked by long drought nearly as hard as bricks" and water scarcity was becoming widespread (COD/C52, G. Holborow to C. Codrington, 12 June 1863). Thereafter, references to extremely dry conditions persisting until autumn 1864 are abundant, and one year later Antigua's governor recalled this as a time of "unprecedented Drought extending over twenty months" (CO7/126, O. Eldridge to Gov. Hill, 21 August 1865). No major breaks in the dry spell were identified; however, the Moravians observed transient rains late in the 1863 wet season.

The final multi-year drought period in this study spans 1870-71 to 1873-74. Missionary papers indicate belowaverage precipitation in the vicinity of Gracefield and Newfield stations from early to mid-1871, abundant rains immediately after a hurricane in late August and the premature cessation of the year's wet season throughout Antigua. From then until the arrival of continuous heavy rains in October 1874, recurrent drought is recorded extensively. This was apparently punctuated by short, localised showery spells in autumn 1872 and at the start of that and the following year. Nonetheless, early in 1875, Brother T. Zippel of Gracehill reflected the following:

The sufferings of our people from the long seasons of drought and poverty, which have followed one upon another since the hurricane of 1871, it would be useless to describe... The island is now on the point of reaping a harvest, the like of which has not been seen for four or five years. (PA, Vol. 29, p. 329, Gracehill annual report 1874)

Three years later, Antigua's "colonial secretary" wrote in detail of the general economic ruin and water shortages consequent of the "succession of severe droughts" from 1871 to 1874 (CO152/129, Report of E. Baynes, 14 May 1877).

\subsection{Major wet periods}

The earliest prolonged wet period in the climate chronologies spans 1771-74. Rain-year 1771-72 started with precipitation scarcity, but plantation correspondence reported the arrival of abundant general rains in late July and, in December, Antigua's Governor reflected that "uncommonly propitious Weather" had prevailed since mid-August (CO152/32, Gov. Payne to Earl Dartmouth, 19 December 1772). The following rain-year saw another dry winter/spring, after which 


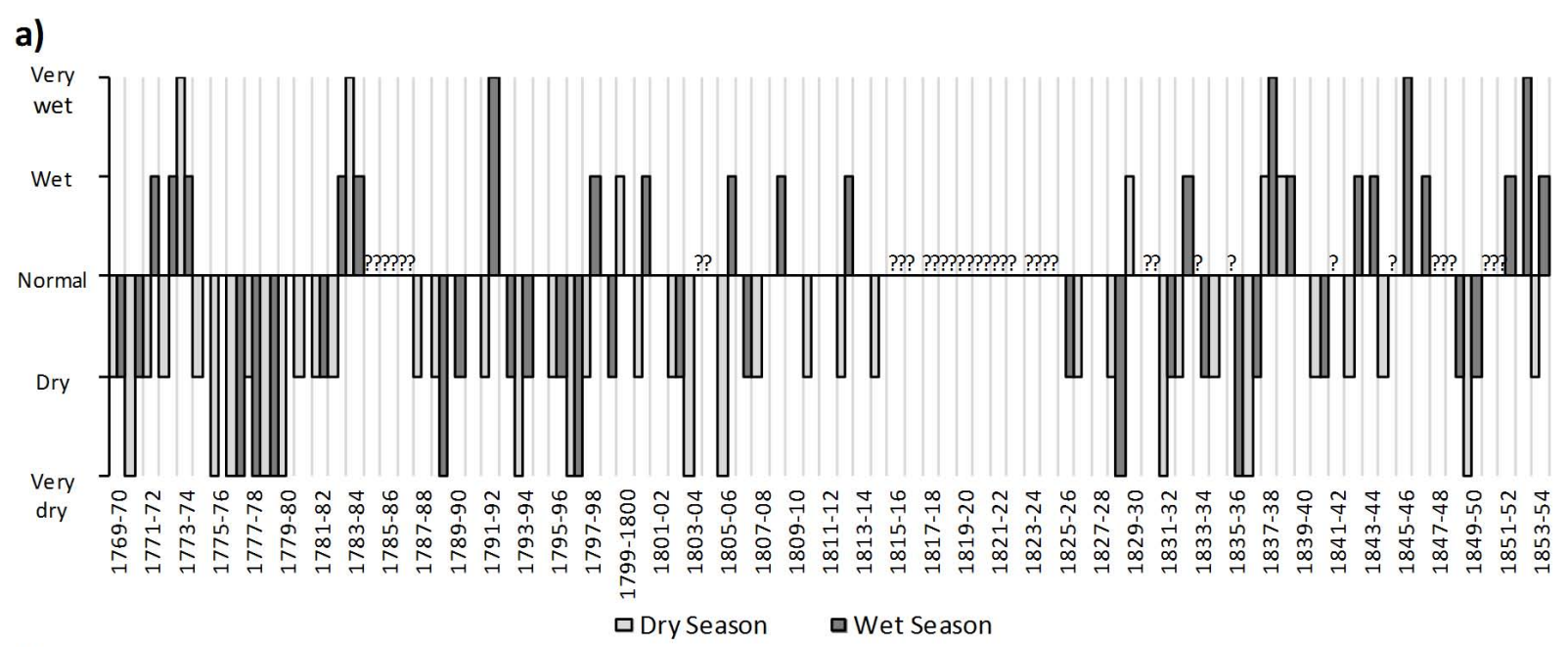

b)

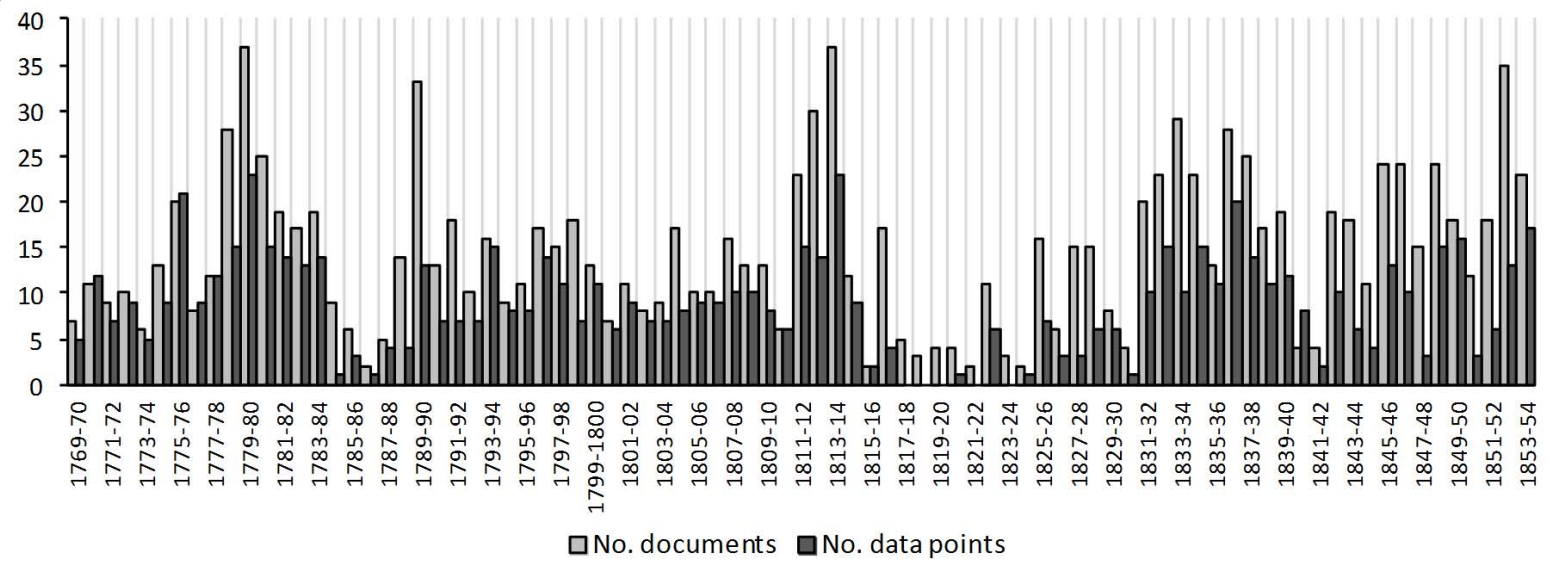

Fig. 5. (a) Document-derived chronology of predominant rainfall conditions experienced at Tudway and Codrington estates in central-eastern Antigua, rain-years 1769-70 to 1853-54. ? denotes unclassified rain-years. (b) Number of documents and data points available for each rainyear.

various sources registered continuous wet weather until autumn 1775. For instance, early that year the Tudways' Antiguan attorney commented that "great falls of rain... for sixteen months from ye middle of June 1773 to ye latter end of September 1774" had damaged sugar crops "universally" (DD/TD/15/6, S. Blizard to C. Tudway, 15 March 1775). Central-eastern plantation papers recorded a similar sequence of conditions in the early-mid-1770s.

Between the 1780s and 1820s, six isolated "wet" rainyears were registered throughout Antigua, though this may reflect the paucity of conclusive weather references for that period (Fig. 3). Extremely wet conditions are next exhibited clearly during the rain-years 1833-34 and 183738. Precipitation abundance was first reported in February 1834, when, according to the Gracehill mission diary, there was "so much storm and rain, that the oldest inhabitants never remembered the like at this season" (PA, Vol. 13, p. 233, Gracehill diary 1834). Missionary and plantation papers recorded intermittent downpours during the subsequent five months, while assembly-member William Byam commented that from August to December "heavy torrents of rain, washes, \&c. [etc.] prevailed" (CO7/42, Report of N. Nugent, July 1835). Another government official asserted that 60.83 inches $(\sim 1545 \mathrm{~mm})$ of rain had fallen during 1834 (Ibid.). Although the reliability of this figure cannot be verified, if comparable with nation-wide ABMS data, it would be among the eleven highest annual precipitation totals from 1928 to 2011. Interestingly, the Tudway plantations and their surroundings appear not to have received the heavy rains experienced elsewhere, estate supervisors reporting predominantly dry weather throughout 1833-34. By contrast, unusually high precipitation levels were recorded universally in 1837-38. One mission diary noted

the quantity of rain which fell during the year was very remarkable, being much greater than anyone could remember in former years... and the whole island presented a fresh and luxuriant appearance... The attendance at church and school 
a)

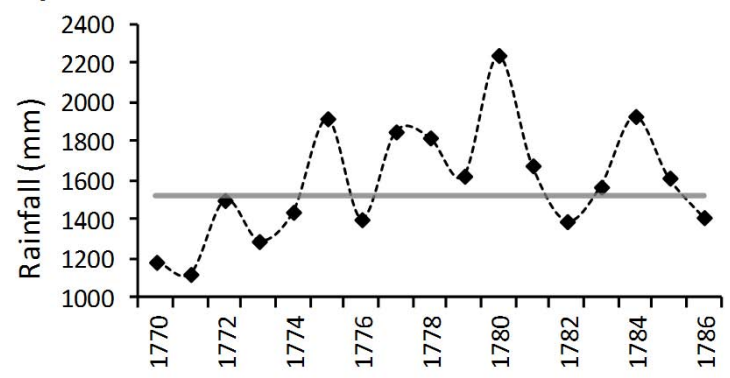

b)

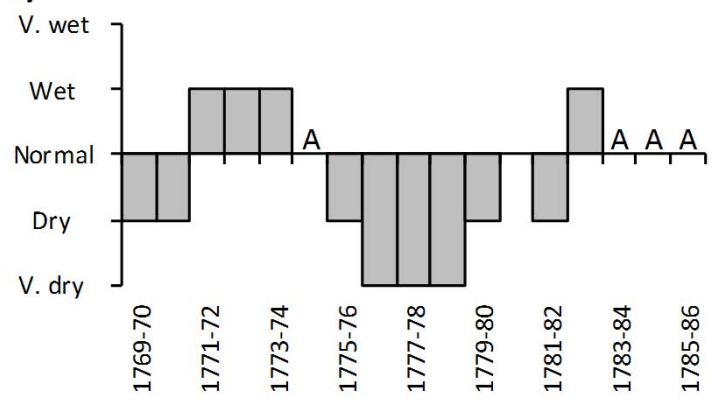

Fig. 6. (a) Annual rainfall totals calculated from daily measurements taken at Savanna-la-Mar, western Jamaica, calendar years 1770 to 1786 (after Chenoweth, 2003). Solid grey line represents mean of annual totals, 1761-86. (b) Documentary-derived chronology of average rainfall conditions throughout Antigua, rain-years $1769-70$ to $1785-86$. A denotes assumed 'normal' classification.

was, however, often thinned by the floods which poured down in such abundance. (PA, Vol. 15, p. 79, Gracehill station diary 1838)

The period 1841-46 was largely wet but interrupted by drought in 1844-45. Various government papers report the arrival of summer rains in June 1842 after a five-month dry spell. The remainder of the wet season purportedly witnessed abundant precipitation, with flooding in late August. For instance, in his quarterly report, stipendiary magistrate Robert Horsford commented

the country had been refreshed by frequent showers through the month of July and the early part of August, towards the end of which... the island was visited by one of the heaviest falls of rain ever remembered - a perfect deluge - which in the course of a few hours overflooded [sic] the entire face of the country; in the flat lands to a depth of several feet... (CO7/74, Report of R. Horsford, 30 September 1842)

A similar pattern characterised $1842-43$, with rainfall scarcity from February to May and regular rains thereafter. Wet-season precipitation was, however, commonly described as plentiful, rather than excessive. A continuance of "unusually favourable" weather from then until early
1845 was recorded by Antigua's "General Agricultural Society" ( $\mathrm{T} \backslash \mathrm{PH} \backslash \mathrm{swd} / 3$, General Agricultural Society report, August 1845) - an observation supported by numerous government and plantation papers. The best-documented rain-year of above-average precipitation was 1845-46, with 22 individual weather references. In early August, Morvian Allen Hamilton noted

this season has been and still is most propitious for future crops; we never experienced such constant rains as have fallen during the last three months. (PA, Vol. 18, p. 40, Letter from A. Hamilton, 11 August 1846)

Weeks later the whole island was said by one estate manager to be "deluged" (COD/C30, J. Winter to C. Codrington, 27 August 1846) and the following May, Governor Higginson recollected the widespread occurrence of "heavy and continuous rains" throughout autumn (CO7/86, Gov. Higginson to Earl Grey, 26 May 1847).

There was sustained above-average rainfall from 1878 to 1881 , with especially wet conditions in 1878-79. Various missionaries echoed the remarks of Antigua's chief medical officer that 1879 was a year "of unusual severity as regards the quantity of rain which fell" (CO152/138, Report of W. Edwards and A. Edwards, 9 April 1880). Conditions that year appear to have been consistently wet. The annual statement for Gracehill mission, for example, noted that Antigua had received an "abundance of rain... pretty evenly throughout the year" without "a single dry month" (PA, Vol. 31, p. 365, Gracehill report 1879). As in 1878-79, periodical reports furnished most climate references in subsequent rain-years. Government returns for 1880 enumerated the infrastructural damage produced by "excessive" precipitation that year. Meanwhile, mission papers reported "fruitful seasons" throughout Antigua from July 1880 to mid-1881, with "heavy rains" at Cedarhall (PA, Vol. 32, p. 98, Annual Report July 1880-July 1881), and persistently wet weather in the remainder of the 1881 wet season.

\section{Discussion and conclusions}

This work represents the first archival investigation of longterm historical precipitation variability in the Lesser Antilles, and one of few in the Caribbean at large. Findings should be interpreted with consideration of the socio-economic context in which the consulted documentation was produced. The prosperity of all sectors of colonial Antiguan society was linked tightly with the success of the sugar industry. Sugarcane agriculture followed a continuous annual cycle timed around typical seasonal weather patterns, with planting staggered in the wettest months of June to November and canes harvested from January to June (Sheridan, 1974; Dyde, 2000). Although climatic conditions were, therefore, regularly commented upon generally, it is conceivable that 
meteorological conditions causing notable disruptions to this pattern were best documented. This may partly explain why more relatively dry episodes were identified than wet ones (Table 3); consistently wet weather, unless extreme or coinciding with harvest, would largely have allowed plantation agriculture to proceed in a normal manner and may have avoided extensive commentary. Furthermore, Antigua's predominantly limestone geology and lack of permanent surface water features reduces the potential for major floods with profound societal impacts. Conversely, drought had readily perceptible consequences for agro-economic productivity and water supplies.

Another important consideration is the potential for observers to exaggerate the severity of, or give undue attention to, adverse weather during times of socio-economic breakdown. Such potential inaccuracies are inherent in historical climate research. Here, they have been accounted for through cross-comparison of multiple observations and careful reference to contextual information in the archives and historical scholarship. The dry episode of 1775-76 to 1781-82 merits particular attention, coinciding with the American War of Independence (1775-83) and consequent trade embargo. These are recognised to have triggered an unprecedented subsistence crisis throughout the British Lesser Antilles (Sheridan, 1976; Dyde, 2000). Exogenous stresses on food supplies may have resulted in the documentation of episodes of rainfall scarcity that would otherwise have received little or no mention. This could account for the relatively high number of data points in this period (Fig. 3b). Nonetheless, recurrent direct descriptions of the duration of rainfall scarcity, water shortages and their impacts on crops provide substantial evidence of severe drought spells at the time.

Examination of the island-wide and central-eastern climate chronologies reveals largely good correspondence between these independent data series. As would be expected, this is particularly so when comparing annual classifications in the former with wet-season classifications in the latter (Kendall Tau-b correlation coefficient of 0.72 , significant at the 0.01 level). Nonetheless, classification counts (Table 3) suggest that the central-eastern Antiguan sources were particularly biased towards recording drier-than-normal conditions. The relatively limited potential for wet weather to disrupt sugar production - discussed above - may explain this. Another factor is the location of the studied estates in a part of the island characterised by lower average precipitation. Correspondents occasionally described the weather with reference to that experienced elsewhere in the island. It is possible that their writings may often have expressed meteorological conditions relative to what was perceived as normal in Antigua generally, without explicitly stating so.

Despite the methodological limitations highlighted, the documentary-derived reconstruction presented here corresponds well with two separate series of unstandardised instrumental data spanning 16-21 yr (Fig. 4). Findings afford separate annually and seasonally resolved chronologies of relative precipitation variations, respectively covering 84 and $121 \mathrm{yr}$ beyond the modern instrumental record, which are unique in the Caribbean. A total of 42 (25) rain-years of predominantly drier-than-normal (wetter-than-normal) conditions throughout Antigua were identified, the incidence of which is summarised by Fig. 3a. "Dry" or "very dry" classifications were assigned every 2.88 rain-years on average in the island-wide reconstruction. This is not completely divergent from the modern climatology of the ABMS, which defines "slight" to "severe" drought as the lowest $30 \%$ of precipitation totals on record (i.e. occurring every $\sim 3.33 \mathrm{yr}$ ). It is noteworthy that 3-5 successive years of drought, such as those identified in the 1770s, 1830s and 1870s, are also present in modern instrumental data.

Assessment of the wider palaeoclimatic significance of this study is hampered by the shortage of high-resolution reconstructions of rainfall variability in the Caribbean. No correspondence is evident between the Antiguan chronology and a document-based drought time series for the Yucatan Peninsula (Mendoza et al., 2007), which reveals phases of no drought in the periods of 1774-1799 and 1855-1880 and one of frequent droughts in the period of 1800-1855. Similarly, comparison with rainfall measurements taken at Savanna-laMar, Jamaica, from 1760 to 1786 exhibits a lack of coherency (Fig. 6). Chenoweth (2003) asserts that low rainfall levels in the Savanna-la-Mar record from 1768 to 1771, as well as co-located temperature measurements and concurrent severe drought in Mexico, India and throughout Jamaica, could be suggestive of a warm ENSO event with global effects. Although evidence of rainfall scarcity in Antigua in the rainyears 1769-71 does not detract from Chenoweth's assertion, ENSO chronologies based on South American documents do not record any El Niño events in that period (Ortlieb, 2000; Garcia-Herrera et al., 2008). Preliminary comparisons have also been made between results for Antigua and other highresolution proxy climate records that are available for the circum-Caribbean (e.g. Kilbourne et al., 2008; Stahle et al., 2011), as well as indices of climatic variables such as ENSO and NAO (not shown). These demonstrate some periods of consistent behaviour (e.g. the late 1700s), but no clear relationships suggestive of straightforward correlations and simple climatological mechanisms. Such findings are, perhaps, unsurprising given the large distances between the locations studied, the scarcity of records of comparable resolution and the fundamental differences between documentary records and palaeoclimatic proxies. Furthermore, the Caribbean is known to be influenced by the complex interaction of multiple independent drivers of annual to multi-decadal climate variability. The extent to which observed local precipitation variations will reflect any one of these remains to be established consistently. This paper has presented a novel dataset which, alongside other reconstructions of historical rainfall variability in the region, can be used for detailed investigations of such linkages in the future. 
Acknowledgements. This research was funded by a three-year doctoral studentship provided by the Faculty of Social Sciences, University of Nottingham. Thanks go to James Lewis and Nicholas Nugent for help accessing historical rainfall data and maps, as well as the staff of the various archives visited throughout 2011 and 2012. Constructive comments made by four reviewers on an earlier version of this paper are apreciated. The authors are especially grateful to the Austin family and Felicity Dunnett for providing accommodation while undertaking data collection.

Edited by: J. Guiot

\section{References}

ABMS [Antigua and Barbuda Meteorological Service]: Climate Data, available at: www.antiguamet.com (last access: 22 February 2013), 2013.

Auchinleck, G. G.: The rainfall of Antigua and Barbuda. Compiled from Available records, Antigua Sugar Association, St. John's, 1956.

Brazdil, R., Pfister, C., Wanner, H. von Storch, H., and Luterbacher, $\mathrm{J}$ : Historical climatology in Europe - the state of the art, Clim. Change, 70, 363-430, 2005.

Chenoweth, M.: The 18th century climate of Jamaica: derived from the journals of Thomas Thistlewood, 1750-1786, American Philosophical Society, Philadelphia, 2003.

Chenoweth, M.: A reassessment of historical Atlantic Basin tropical cyclone activity, 1700-1855, Clim. Change, 76, 169-240, 2006.

Collins, J.: The case of the sugar colonies, London, 1792.

Dyde, B.: A history of Antigua: the unsuspected isle, Macmillian Education, London, 2000.

Endfield, G. H.: Archival explorations of climate variability and social vulnerability in colonial Mexico, Clim. Change, 83, 9-38, 2007.

Farrell, D., Trotman, A., and Cox, C.: Drought early warning and risk reduction: a case study of the Caribbean drought of 20-2010. UNISDR Global Assessment Report on Disaster Risk Reduction, Geneva, Switzerland, 2010.

Garcia-Herrera, R., Diaz, H. F., Garcia, R. R., Prieto, M. R., Barriopedro, D., Moyano, R., and Hernández, E.: A chronology of El Niño events from primary documentary sources in northern Peru, J. Climate, 21, 1948-1962, 2008.

Gianni, A., Kushnir, Y., and Cane, M. A.: Interanual variability of Caribbean rainfall, ENSO, and the Atlantic Ocean, J. Climate, 13, 297-311, 2000.

Gianni, A., Cane, M. A., and Kushnir, Y.: Interdecadal changes in the ENSO teleconnetion to the Caribbean region and the North Atlantic Oscillation, J. Climate, 14, 2867-2879, 2001a.

Gianni, A., Kushnir, Y., and Cane, M. A.: Seasonality in the impact of ENSO and the North Atlantic High on Caribean rainfall, Phys. Chem. Earth, 26, 143-147, 2001b.

Hastenrath, S.: Variations in low-altitude circulation and extreme climatic events in the tropical Americas, J. Atmos. Sci., 33, 202$215,1976$.
Kelso, C. and Vogel, C.: The climate of Namaqualand in the nineteenth century, Clim. Change, 83, 357-380, 2007.

Kilbourne, K. H., Quinn, T. M., Webb, R., Guilderson, T., Nyberg, J., and Winter, A.: Paleoclimate proxy perspective on Caribbean climate since the year 1751: evidence of cooler temperatures and multidecadal variability, Paleoceanography, 23, PA3220, doi:10.1029/2008PA001598, 2008.

Lanaghan: Antigua and the Antiguans: a full accounts fo the colony and its inhabitants from the time of the Cribs to the present day, interspersed with anecdotes and legends. Also, An impartial view of slavery and the free labour systems; the statistics of the island, and biographical notices of the principal families, Volume I, Saunders and Otley, London, 1844.

Magrin, G., Gay-Garcia, C., Cruz-Choque, D., Giménez, J. C., Moreno, A. R., Nagy, G. J., Nobre, C., and Villamizar, A.: Latin America, in: Climate Change 2007: Impacts, Adaptation and Vulnerability. Contribution of Working Group II to the Fourth Assessment Report of the Intergovernmental Panel on Climate Change, edited by: Parry, M. L., Canziani, O. F., Palutikof, J. P., Van Der Linden, P. J., and Hansen, C. E., Cambridge University Press, Cambridge, 2007.

Mendoza, B., García-Acosta, V., Velasco, V. Jáuregui, E., and DíazSandoval, R.: Frequency and duration of historical droughts from the 16th to 19th centuries in the Mexican Maya lands, Yucatan Peninsula, Clim. Change, 83, 151-168, 2007.

Mock, C.: Paleodroughts and society, in: Encyclopedia of Quaternary Science, edited by: Elias, S. A., Elsevier, Oxford, 2007.

Nash, D. J. and Endfield, G. H.: A 19th century climate chronology for the Kalahari region of central southern Africa derived from missionary correspondence, Int. J. Climatol., 22, 821-841, 2002.

Nash, D. J. and Grab, W.: "A sky of brass and burning winds": documentary evidence of rainfall variability in the Kingdom of Lesotho, Southern Africa, 1824-1900, Clim. Change, 101, 617653, 2010.

Nicholson, T.: An essay on yellow fever. Comprising the history of that disease, as it appeared in the island of Antigua in the years $1835,1839, \& 1842$. With an appendix continuing the history to 1853, London, 1866.

Oliver, V. L.: The history of the island of Antigua, one of the Leeward Caribbees in the West Indies, from the first settlement in 1635 to the present time, Volume I, Mitchell and Hughes, London, 1894.

Ortlieb, L.: The documented historical record of El Niño events in Peru: an update of the Quinn record (sixteenth through nineteenth centuries), in: El Niño and the southern oscillation, multiscale variability and global and regional impacts, edited by: Diaz, H. F. and Markgraf, V., Cambridge University Press, Cambridge, 2000.

Pfister, C., Brázdil, R. Glaser, R., Barriendos, M., Camuffo, D., Deutsch, M., Dobrovolny, P., Enzi, S., Guidoboni, E., Kotyza, O., Militzer, S., Rácz, L., and Rodrigo, F. S.: Documentary evidence on climate in sixteenth-century Europe, Clim. Change, 43, 55-110, 1999.

SFG [Society for the Furtherance of the Gospel]: Retrospect of the history of the mission of the Brethren's Church in Antigua, for the past hundred years, William Tyler, London, 1856.

Sheridan, R. B.: Sugar and slavery: an economic history of the British West Indies, 1623-1775, Hopkins University Press, Baltimore, 1974. 
Sheridan, R. B.: The crisis of slave subsistence in the British West Indies during and after the American Revolution, The William and Mary Quarterly, 33, 615-641, 1976.

Stahle, D. W., Burnette, D. J., Villanueva-Diaz, J., Heim, R. R., Fye, F. K., Cerano-Paredes, J., Acuña-Soto, R., and Cleaveland, M. K.: Pacific and Atlantic influences on Mesoamerican climate over the past millennium, Clim. Dynam., 39, 1431-1446, 2011.

Sturge, J. and Harvey, T.: The West Indies in 1837. Being the journal of a visit to Antigua, Montserrat, Dominica, St. Lucia, Barbados, and Jamaica. Undertaken for the purpose of ascertaining the actual condition of the negro population of those Islands, Hamilton, Adams, \& Co., London, 1838
Taylor, M. and Alfaro, E.: Climate of Central America and the Caribbean, in: Encyclopedia of World Climatology, edited by: Oliver, J. E., Springer, Dordrecht, 2005.

Young, W.: A tour through the several island of Barbadoes, St. Vincent, Antigua, Tobago, and Grenada, in the years 1791 and 1792, in: An historical survey of the island of Saint Domingo together with an account of the maroon negroes in the island of Jamaica; and a History of the war in the West Indies, in 1793, and 1794, edited by: Edwards, B., London, 1801. 